\title{
PENGARUH JUMLAH DAUN DAN KONSENTRASI ROOTONE-F TERHADAP PERTUMBUHAN BIBIT JERUK NIPIS LEMON (Citrus limon L.) ASAL STEK PUCUK
}

\author{
The Effect of the Number of Leaves and Concentration of Rootone-F on the Growth of Lemon \\ Lime (Citrus limon L.) Seedling from Shoot Cuttage)
}

Puspita Sari, Yazid Ismi Intara, dan Alvera Prihatini Dewi Nazari

Program Studi Agroekoteknologi, Fakultas Pertanian, Universitas Mulawarman. Jl. Pasir Balengkong, Kampus Gunung Kelua, Samarinda 75119, Kalimantan Timur, Indonesia.

E-Mail: Puspitasari7382@gmail.com

Article Submitted : 16-08-2019

Article Accepted : 05-10-2019

\begin{abstract}
The research was conducted to know the interaction between the number of leaves and concentration of Rootone-F; the effect of the number of leaves; and concentration of Rootone-F on the growth of lemon lime seedling from shoot cuttage singly. The experiment was conducted from November 2017 until Febuary 2018, on Faculty of Agriculture, Mulawarman University. The factorial experiment was arranged in Completely Randomized Design with five replications. The first factor was the number of leaves, consisted of: 5, 7 and 9 leaves, while the second factor was concentration of Rootone-F, consisted of: $0.00 ; 0.05 ; 0.10$; and $0.15 \mathrm{~g} \mathrm{~mL}^{-1}$. Variables which observed consisted of: time of bud emergence, the number of buds, the number of leaves, bud length, bud diameter, the number of roots and root length. Data were analyzed by analysis of variance and continued by Least Significant Difference test at 5\% of significant level. The result showed that the interaction between the number of leaves and concentration of Rootone- $F$ has no significant on variables observed, unless on bud diameter. The effect of the number of leaves has significantly different on variables observed, however, it has no significant on the number of buds, the number of leaves and bud length at 12 weeks after planting (WAP). The concentration of Rootone-F effect has significantly different on variables observed, unless on the number of buds and the number of leaves at 6 WAP. The best growth of lemon lime seedling obtained by nine leaves and $0.10 \mathrm{~g}$ Rootone-F $\mathrm{mL}^{-1}$ singly.
\end{abstract}

Keywords: lemon lime, number of leaves, Rootone-F, shoot cottage

\section{PENDAHULUAN}

Jeruk nipis lemon merupakan salah satu tanaman hortikultura yang cukup dikenal masyarakat, pada umumnya ditanam di pekarangan sebagai tanaman apotek hidup. Buah jeruk nipis lemon mengandung vitamin, mineral dan serat, sering dipakai sebagai penambah rasa dalam kuliner khas daerah, sehingga mempunyai nilai ekonomi yang cukup tinggi. Prospek pemasaran buah jeruk nipis lemon di Kalimantan Timur sangat cerah, namun pengembangan tanaman ini belum maksimal dan perannya dalam perekonomian daerah masih rendah, hal ini ditunjukkan dengan belum adanya data produksi jeruk nipis lemon. Salah satu hambatan dalam pengembangan tanaman ini adalah ketersediaan bibit atau bahan tanam yang berkualitas. Upaya yang dapat dilakukan untuk mengatasi masalah tersebut adalah melalui penerapan teknologi pembibitan yang cepat dan menjamin keseragaman dan kestabilan hasil untuk memenuhi kebutuhan bibit unggul jeruk di 
Kalimantan Timur (Badan Pusat Statistik, 2016).

Perbanyakan tanaman jeruk nipis lemon dapat dilakukan dengan beberapa cara, salah satu diantaranya dengan menggunakan stek. Salah satu diantara beberapa metode penyetekan adalah stek pucuk. Keuntungan menggunakan stek pucuk adalah lebih mudah berakar dibandingkan menggunakan bagian tanaman yang tua karena bagian tanaman yang tua mengandung zat penghambat perakaran yang lebih tinggi dan kadar senyawa fenolik lebih rendah yang berperan sebagai kofaktor yang mendukung inisiasi akar pada stek (Wudianto, 2003). Keberhasilan perbanyakan dengan cara stek ditandai dengan terjadinya regenerasi akar dan pucuk pada bahan stek sehingga menjadi tanaman baru yang memiliki sifat yang sama dengan induknya (Widiarsih et al, 2008).

Daun dapat meningkatkan pertumbuhan bibit asal stek karena mengandung klorofil yang berperan dalam fotosintesis, proses yang membantu dalam penyediaan cadangan makanan yang cukup pada pertumbuhan awal stek secara cepat, sehingga mampu memacu pertumbuhan selanjutnya, khususnya akar. Semakin banyak jumlah daun, proses fotosintesis semakin giat, dengan demikian fotosintat yang dihasilkan cukup tersedia untuk meningkatkan pertumbuhan bibit asal stek.

Selain daun, perakaran yang baik dan sehat sangat diperlukan dalam perbanyakan tanaman dengan cara stek, karena akar berfungsi menyerap air dan unsur hara untuk pertumbuhan bibit asal stek. Pertumbuhan, diferensiasi dan percabangan akar dipengaruhi oleh auksin. Rootone-F merupakan salah satu merk dagang zat pengatur tumbuh (ZPT) yang dapat dipakai untuk memacu pembentukan dan pertumbuhan akar pada stek karena mengandung auksin sintetik.

Tujuan penelitian adalah untuk mengetahui: 1) interaksi antara jumlah daun dan konsentrasi Rootone-F; 2) pengaruh jumlah daun dan 3) pengaruh konsentrasi Rootone-F terhadap pertumbuhan bibit jeruk nipis lemon asal stek pucuk.

\section{METODE PENELITIAN}

\section{Tempat dan Waktu}

Penelitian percobaan dilaksanakan di Fakultas Pertanian, Universitas Mulawarman, sejak bulan November 2017 sampai dengan Februari 2018.

\section{Bahan dan Alat}

Bahan yang dipakai terdiri atas: stek pucuk jeruk nipis lemon dengan jumlah daun sesuai perlakuan (5, 7 dan 9 helai), Rootone-F, tanah, pupuk kotoran sapi, sekam padi, polibag berukuran $8 \mathrm{~cm} \times 15$ $\mathrm{cm}$, paranet $25 \%$ dan kertas label.

Alat yang dipakai terdiri atas: cutter, gunting stek, cangkul, califer, ayakan, ember, handsprayer, alat tulis, alat dokumentasi dan timbangan digital.

\section{Rancangan Penelitian}

Percobaan faktorial $3 \times 4$ disusun dalam Rancangan Acak Lengkap (RAL). Faktor pertama adalah jumlah daun pada stek pucuk, terdiri atas tiga taraf, yaitu 5; 7 dan 9 helai daun. Faktor kedua adalah konsentrasi Rootone-F, terdiri atas empat taraf, yaitu 0,$00 ; 0,05 ; 0,10$ dan $0,15 \mathrm{~g} \mathrm{~mL}^{-1}$. Setiap perlakuan dilakukan sebanyak lima ulangan.

\section{Pelaksanaan Penelitian}

Kegiatan penelitian terdiri atas: pembuatan naungan yang dibuat dari dua lapis paranet $25 \%$, persiapan media tanam, persiapan bahan tanam (stek pucuk), penanaman dan pemeliharaan.

Media tanam terdiri atas campuran tanah, pupuk kotoran sapi dan sekam padi dengan perbandingan 1:2:3. Bahan stek diambil dari pohon induk yang telah berumur 2 tahun dengan jumlah daun sesuai perlakuan. Stek dipotong dengan arah potongan miring. Rootone-F diberikan sebelum stek ditanam, yaitu dengan cara merendam pangkal stek sepanjang $5 \mathrm{~cm}$ dalam larutan Rootone-F sesuai dengan perlakuan $(0,00 ; 0,05 ; 0,10$ dan $\left.0,15 \mathrm{~g} \mathrm{~mL}^{-1}\right)$. Perendaman dilakukan selama 60 menit. Setelah direndam, stek 
ditanam sedalam $\pm 5 \mathrm{~cm}$ pada lubang tanam yang telah disiapkan.

\section{Pengamatan}

Variabel yang diamati terdiri atas: saat muncul tunas terhadap tunas yang muncul berukuran $\pm 1 \mathrm{~cm}$, dihitung dalam hari setelah tanam (HST), jumlah tunas, jumlah daun, panjang tunas terpanjang, diameter tunas, jumlah akar dan panjang akar.

Pengambilan data jumlah tunas, jumlah daun dan panjang tunas terpanjang dilakukan pada 6 dan 12 minggu setelah tanam (MST), sedangkan data diameter tunas, jumlah akar dan panjang akar diambil pada akhir penelitian, yaitu pada $12 \mathrm{MST}$.

\section{Analisis Data}

Data hasil penelitian dianalisis dengan menggunakan sidik ragam dengan uji $\mathrm{F}$ pada taraf 5\%, apabila hasil sidik ragam menunjukkan pengaruh perlakuan berbeda nyata, maka untuk membandingkan antara dua rata-rata perlakuan dilanjutkan dengan uji Beda Nyata Terkecil (BNT) pada taraf $5 \%$.

\section{HASIL DAN PEMBAHASAN}

Hasil sidik ragam menunjukkan bahwa interaksi antara jumlah daun dan konsentrasi Rootone-F berbeda tidak nyata terhadap semua variabel yang diamati, kecuali diameter tunas. Pengaruh jumlah daun berbeda nyata terhadap saat muncul tunas, jumlah daun dan panjang tunas pada $6 \mathrm{MST}$, diameter tunas, jumlah akar dan panjang akar, tetapi berbeda tidak nyata terhadap jumlah tunas, jumlah daun dan panjang tunas pada 12 MST. Pengaruh konsentrasi Rootone-F berbeda nyata terhadap saat muncul tunas, jumlah daun pada 12 MST, panjang tunas, diameter tunas, jumlah akar, dan panjang akar bibit jeruk nipis lemon asal stek pucuk, tetapi berbeda tidak nyata terhadap jumlah tunas pada 6 dan 12 MST dan jumlah daun pada 6 MST. Rekapitulasi hasil penelitian disajikan pada Tabel 1 berikut.

Tabel 1. Rekapitulasi Hasil Penelitian Pengaruh Jumlah Daun dan Konsentrasi Rootone-F terhadap Pertumbuhan Bibit Jeruk Nipis Lemon Asal Stek Pucuk

\begin{tabular}{|c|c|c|c|c|c|c|c|c|c|c|}
\hline \multirow[t]{2}{*}{ Perlakuan } & \multirow{2}{*}{$\begin{array}{c}\text { Saat } \\
\text { Muncul } \\
\text { Tunas } \\
\text { (HST) }\end{array}$} & \multicolumn{2}{|c|}{$\begin{array}{l}\text { Junlah Tunas } \\
\text { (buah) }\end{array}$} & \multicolumn{2}{|c|}{$\begin{array}{c}\text { Jumlah Daun } \\
\text { (helai) }\end{array}$} & \multicolumn{2}{|c|}{$\begin{array}{l}\text { Panjang Tunas } \\
\text { (cm) }\end{array}$} & \multirow{2}{*}{$\begin{array}{c}\begin{array}{c}\text { Diameter } \\
\text { Tunas } \\
(\mathrm{cm})\end{array} \\
12 \\
\text { MST }\end{array}$} & \multirow{2}{*}{$\begin{array}{c}\begin{array}{c}\text { Jumlah } \\
\text { Akar } \\
\text { (akar) }\end{array} \\
12 \\
\text { MST }\end{array}$} & \multirow{2}{*}{$\begin{array}{c}\begin{array}{c}\text { Panjang } \\
\text { Akar } \\
(\mathrm{cm})\end{array} \\
12 \\
\text { MST }\end{array}$} \\
\hline & & $\begin{array}{c}6 \\
\text { MST } \\
\end{array}$ & $\begin{array}{c}12 \\
\text { MST }\end{array}$ & $\begin{array}{c}6 \\
\text { MST } \\
\end{array}$ & $\begin{array}{c}12 \\
\text { MST }\end{array}$ & $\begin{array}{c}6 \\
\text { MST } \\
\end{array}$ & $\begin{array}{c}12 \\
\text { MST }\end{array}$ & & & \\
\hline $\begin{array}{c}\text { Jumlah } \\
\text { Daun (D) } \\
\text { (helai) } \\
\end{array}$ & $*$ & tn & tn & $*$ & tn & $*$ & tn & 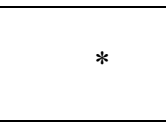 & $*$ & $*$ \\
\hline $\mathrm{d}_{1}=5$ & $8,60 \mathrm{~b}$ & 1,15 & 1,25 & $7,30 \mathrm{ab}$ & 19,65 & $8,26 a$ & 22,80 & $0,16 a$ & $27,65 a$ & $20,99 a$ \\
\hline $\mathrm{d}_{2}=7$ & $7,80 \mathrm{~b}$ & 1,05 & 1,30 & $6,40 \mathrm{a}$ & 14,75 & $8,32 \mathrm{a}$ & 24,75 & $0,17 \mathrm{a}$ & $33,65 \mathrm{a}$ & $22,01 \mathrm{a}$ \\
\hline $\mathrm{d}_{3}=9$ & $6,75 a$ & 1,30 & 1,60 & $8,55 \mathrm{~b}$ & 19,95 & $10,74 \mathrm{~b}$ & 25,15 & $0,23 b$ & $40,65 \mathrm{~b}$ & $23,95 \mathrm{~b}$ \\
\hline $\begin{array}{c}\text { Nilai } \\
\mathrm{BNT}_{0,05}\end{array}$ & 0,94 & - & - & 1,57 & - & 1,98 & - & 0,03 & 7,61 & 2,28 \\
\hline $\begin{array}{l}\text { Konsentrasi } \\
\text { Rootone-F } \\
\text { (F) }\left(\mathrm{g} \mathrm{mL}^{-1}\right)\end{array}$ & $*$ & tn & tn & tn & $*$ & $*$ & $*$ & * & $*$ & $*$ \\
\hline $\mathrm{f}_{0}=0,00$ & $9,07 \mathrm{~b}$ & 1,20 & 1,33 & 6,47 & $14,20 \mathrm{a}$ & $6,97 a$ & $16,62 \mathrm{a}$ & $0,16 \mathrm{a}$ & $24,93 a$ & $17,46 \mathrm{a}$ \\
\hline$f_{1}=0,05$ & $7,20 \mathrm{a}$ & 1,00 & 1,27 & 7,40 & $23,33 b$ & $9,10 \mathrm{a}$ & $29,07 b$ & $0,22 b$ & $36,47 b$ & $25,83 \mathrm{c}$ \\
\hline $\mathrm{f}_{2}=0,10$ & $7,07 \mathrm{a}$ & 1,20 & 1,27 & 8,33 & $20,60 \mathrm{~b}$ & $11,47 b$ & $26,75 b$ & $0,18 \mathrm{a}$ & $38,47 b$ & $23,31 b$ \\
\hline $\mathrm{f}_{3}=0,15$ & $7,53 \mathrm{a}$ & 1,27 & 1,67 & 7,47 & $20,00 \mathrm{~b}$ & $8,91 \mathrm{a}$ & $24,46 \mathrm{~b}$ & $0,19 \mathrm{a}$ & $36,07 \mathrm{~b}$ & $22,67 \mathrm{~b}$ \\
\hline $\begin{array}{c}\text { Nilai } \\
\mathrm{BNT}_{0,05}\end{array}$ & 1,09 & - & - & - & 5,17 & 2,29 & 5,62 & 0,04 & 8,79 & 2,63 \\
\hline $\begin{array}{c}\text { Interaksi } \\
(\mathrm{DxF})\end{array}$ & tn & tn & tn & tn & tn & tn & tn & $*$ & tn & tn \\
\hline
\end{tabular}




\begin{tabular}{crrrrrrrrrr}
\hline $\mathrm{d}_{1} \mathrm{f}_{0}$ & 10,80 & 1,20 & 1,40 & 7,80 & 16,00 & 6,90 & 16,28 & $0,14 \mathrm{a}$ & 21,20 & 17,60 \\
$\mathrm{~d}_{1} \mathrm{f}_{1}$ & 7,80 & 1,00 & 1,00 & 6,20 & 23,60 & 8,39 & 30,38 & $0,20 \mathrm{a}$ & 32,00 & 21,74 \\
$\mathrm{~d}_{1} \mathrm{f}_{2}$ & 7,80 & 1,20 & 1,20 & 7,60 & 20,80 & 10,40 & 26,56 & $0,18 \mathrm{a}$ & 30,40 & 22,76 \\
$\mathrm{~d}_{1} \mathrm{f}_{3}$ & 8,00 & 1,20 & 1,40 & 7,60 & 18,20 & 7,40 & 17,98 & $0,15 \mathrm{a}$ & 27,00 & 21,86 \\
$\mathrm{~d}_{2} \mathrm{f}_{0}$ & 8,60 & 1,00 & 1,20 & 4,80 & 13,00 & 4,90 & 15,78 & $0,13 \mathrm{a}$ & 23,00 & 16,92 \\
$\mathrm{~d}_{2} \mathrm{f}_{1}$ & 7,40 & 1,00 & 1,60 & 5,80 & 21,60 & 7,54 & 24,86 & $0,16 \mathrm{a}$ & 31,40 & 27,36 \\
$\mathrm{~d}_{2} \mathrm{f}_{2}$ & 7,40 & 1,00 & 1,20 & 7,40 & 20,20 & 10,40 & 26,30 & $0,13 \mathrm{a}$ & 33,20 & 21,64 \\
$\mathrm{~d}_{2} \mathrm{f}_{3}$ & 7,80 & 1,20 & 1,20 & 7,60 & 27,20 & 10,46 & 32,08 & $0,24 \mathrm{~b}$ & 47,00 & 22,12 \\
$\mathrm{~d}_{3} \mathrm{f}_{0}$ & 7,80 & 1,40 & 1,40 & 6,80 & 13,60 & 9,10 & 17,80 & $0,20 \mathrm{a}$ & 30,60 & 17,86 \\
$\mathrm{~d}_{3} \mathrm{f}_{1}$ & 6,40 & 1,00 & 1,20 & 10,20 & 24,80 & 11,40 & 31,96 & $0,30 \mathrm{~b}$ & 46,00 & 28,40 \\
$\mathrm{~d}_{3} \mathrm{f}_{2}$ & 6,00 & 1,40 & 1,40 & 10,00 & 20,80 & 13,60 & 27,38 & $0,24 \mathrm{~b}$ & 51,80 & 25,52 \\
$\mathrm{~d}_{3} \mathrm{f}_{3}$ & 6,80 & 1,40 & 2,40 & 7,20 & 20,60 & 8,86 & 23,23 & $0,17 \mathrm{a}$ & 34,20 & 24,02 \\
\hline $\mathrm{Nilai}$ & - & - & - & - & - & - & - & 0,07 & - & - \\
$\mathrm{BNT}_{0,05}$ & & & & & & & & & &
\end{tabular}

Keterangan: Angka rata-rata yang diikuti oleh huruf yang sama menunjukkan berbeda tidak nyata dengan uji BNT 5\%

\section{Interaksi Antara Jumlah Daun dan Konsentrasi Rootone-F terhadap Pertumbuhan Bibit Jeruk Nipis Lemon (Citrus limon L.) Asal Stek Pucuk}

Hasil sidik ragam menunjukkan bahwa interaksi antara jumlah daun dan konsentrasi Rootone-F tidak nyata terhadap variabelvariabel yang diamati, kecuali terhadap diameter tunas bibit jeruk nipis lemon asal stek pucuk (Tabel 1). Interaksi antara jumlah daun dan konsentrasi Rootone-F berbeda nyata terhadap diameter tunas diduga berhubungan dengan fungsi daun sebagai organ fotosintesis, semakin banyak jumlah daun, proses fotosintesis akan semakin meningkat. Hal ini ditunjukkan oleh hasil penelitian, diameter tunas tertinggi diperoleh pada perlakuan 9 helai daun dan $0,05 \mathrm{~g}$ Rootone-F $\mathrm{mL}^{-1}$, yaitu $0,30 \mathrm{~cm}$.

Fotosintat hasil fotosintesis dipakai oleh bibit tanaman untuk membentuk organel dan bagian sel, enzim, serta sebagai substrat pada proses respirasi yang menghasilkan energi yang dipakai untuk proses pertumbuhan dan perkembangannya. Pertumbuhan dan perkembangan tanaman merupakan hasil dari proses-proses yang terjadi pada sel, yaitu pembelahan, pembesaran dan diferensiasi sel. Salisbury dan Ross (1995) mengemukakan bahwa pertumbuhan dan perkembangan sel dihasilkan dari tiga peristiwa yang sederhana, yaitu pembelahan, pembesaran, dan diferensiasi sel. Disisi lain, auksin sintetik dari Rootone-F bersama auksin endogen memacu pemanjangan/pembesaran sel dengan tersedianya senyawa organik, terutama karbohidrat dan protein, secara cukup, menyebabkan diameter tunas menjadi lebih besar.

Interaksi antara jumlah daun dan konsentrasi Rootone-F tidak nyata terhadap variabel-variabel: saat muncul tunas, jumlah tunas, jumlah daun, panjang tunas terpanjang, jumlah akar dan panjang akar bibit jeruk nipis lemon asal stek pucuk pada semua umur pengamatan. Hal ini diduga karena kandungan auksin sintetik dalam Rootone-F meningkatkan kadar auksin endogen dalam stek. Kadar auksin yang tinggi menyebabkan tanaman mensintesis ZPT lain, yaitu etilen, yang pengaruhnya berlawanan dengan auksin. Dewi (2008) menjelaskan bahwa pengaruh suatu zat pengatur tumbuh tergantung kepada spesies, konsentrasi dan tempat ZPT bekerja serta fase pertumbuhan. Konsentrasi auksin yang rendah akan memacu pertumbuhan, sebaliknya pada konsentrasi yang tinggi akan menyebabkan tanaman mensintesis etilen yang pengaruhnya berlawanan dengan auksin.

Pengaruh Jumlah Daun terhadap Pertumbuhan Bibit Jeruk Nipis Lemon (C. limon L.) Asal Stek Pucuk 
Hasil sidik ragam menunjukkan bahwa pengaruh jumlah daun berbeda nyata terhadap saat muncul tunas. Rata-rata saat muncul tunas tercepat ditunjukkan oleh perlakuan 9 helai daun, yaitu 6,75 HST, diikuti oleh perlakuan 7 dan 5 helai daun, berturut-turut 7,80 dan 8,60 HST. Hal ini disebabkan ada hubungan erat antara pertumbuhan bibit tanaman dengan ketersediaan cadangan makanan pada stek. Pada awal pertumbuhan stek, akar belum terbentuk, sehingga untuk pertumbuhannya, stek memanfaatkan cadangan makanan, khususnya karbohidrat, sebagaimana dinyatakan oleh Wahid (1990), bahwa karbohidraat yang terkandung dalam bahan stek merupakan faktor utama perkembangan tunas dan akar. Wudianto (2003) menambahkan bahwa pada awal pertumbuhan stek, cadangan makanan yang dikandung dalam bahan stek yaitu karbohidrat sangat mempengaruhi perkembangan tunas stek.

Cadangan makanan yang disimpan dalam stek adalah hasil fotosintesis. Semakin banyak jumlah daun, proses fotosintesis akan semakin meningkat, sehingga cadangan makanan semakin banyak dan dapat dipakai sebagai substrat pada proses respirasi untuk menghasilkan energi yang diperlukan bagi proses pertumbuhan dan perkembangan tanaman.

Hasil sidik ragam pengaruh jumlah daun stek terhadap jumlah tunas bibit jeruk nipis lemon asal stek pucuk pada 6 dan 12 MST menunjukkan berbeda tidak nyata. Perbedaan jumlah daun tampaknya tidak menyebabkan perbedaan jumlah cadangan makanan secara nyata untuk memacu pembentukan tunas walaupun dengan bertambahnya umur bibit (Tabel 1). Menurut Rochiman dan Harjadi (2003), perkembangan daun, akar dan tunas pada tanaman dipengaruhi oleh kandungan cadangan makanan, terutama persediaan karbohidrat dan nitrogen. Disamping itu, jumlah tunas yang dibentuk pada tanaman diduga berhubungan dengan faktor genetik tanaman tersebut, sebagaimana dikemukakan oleh Sitompul dan Bambang (1995) bahwa keragaman tanaman disebabkan oleh perbedaan susunan genetik.

Berdasarkan hasil sidik ragam, pengaruh jumlah daun stek terhadap jumlah daun yang terbentuk pada bibit jeruk nipis lemon menunjukkan berbeda nyata pada umur 6 MST, tetapi berbeda tidak nyata pada umur 12 MST. Rata-rata jumlah daun terbanyak pada umur 6 MST ditunjukkan oleh perlakuan 9 helai daun, yaitu 8,55 helai, sedangkan rata-rata jumlah daun paling sedikit ditunjukkan oleh perlakuan 7 helai daun, yaitu 6,40 helai (Tabel 1).

Pembentukan daun memerlukan cadangan makanan (karbohidrat dan protein) dalam jumlah yang cukup, semakin banyak jumlah daun, proses fotosintesis semakin meningkat, sehingga jumlah cadangan makanan yang disimpan dan kemudian dipakai untuk pertumbuhan semakin meningkat. Gardner et al (1991) mengemukakan bahwa pemunculan dan penambahan helai daun memerlukan sejumlah unsur hara dalam jumlah yang cukup yang akan digunakan dalam pembentukan karbohidrat dan protein. Jumlah karbohidrat dan protein yang cukup akan dapat meningkatkan pertumbuhan akar, batang dan daun secara optimal. Hidayanto et al (2003) menambahkan bahwa panjang stek yang berbeda mempunyai kandungan faktor tumbuh yang berbeda, seperti karbohidrat dan auksin, yang sangat penting perannya terhadap pertumbuhan daun, akar dan tunas.

Hasil sidik ragam pengaruh jumlah daun terhadap panjang tunas bibit jeruk nipis lemon menunjukkan berbeda nyata pada 6 MST, tetapi berbeda tidak nyata pada 12 MST. Proses yang terjadi pada pertumbuhan vegetatif memerlukan karbohidrat dan protein untuk pembentukan dinding sel dan protoplasma Darmawan dan Baharsjah (1983) menjelaskan, ada dua macam pembelahan sel, yaitu pembelahan mitosis dan meiosis. Pembelahan mitosis terjadi 
pada daerah meristem, memerlukan karbohidrat dan protein dalam jumlah sangat besar, menyebabkan pembentukan pucuk, ranting, daun, dan bagian vegetatif lain. Harjadi (1983) menambahkan bahwa pembelahan sel yang terjadi pada titik tumbuh batang dan ujung-ujung akar tergantung pada persediaan karbohidrat yang cukup. Daun berhubungan dalam penyediaan cadangan makanan melalui perannya sebagai organ fotosintesis. Hasil penelitian menunjukkan semakin banyak jumlah daun pada stek, tunas yang terbentuk semakin panjang (Tabel 1).

Hasil penelitian menunjukkan panjang tunas bibit jeruk nipis lemon asal stek pucuk terpanjang pada 6 MST diperoleh pada perlakuan 9 helai daun, yaitu $10,74 \mathrm{~cm}$, sedangkan panjang tunas paling pendek diperoleh pada perlakuan 5 helai daun, yaitu $8,26 \mathrm{~cm}$. Hal ini diduga karena stek dengan kandungan karbohidrat yang banyak akan mampu memacu pertumbuhan awal tunas, sehingga pertumbuhan panjang tunas juga akan lebih cepat. Hal ini sesuai dengan pendapat Edmond et al (1983) yang menyatakan bahwa ketersediaan karbohidrat dan nitrogen sangat menentukan dalam proses pertumbuhan akar dan tunas pada stek. Kehadiran tunas sangat penting dalam proses inisiasi akar, karena akar sebagai tempat penghasil auksin yang akan ditranslokasikan ke dasar potongan stek dan diperlukan untuk diferensiasi sel.

Hasil sidik ragam menunjukkan bahwa pengaruh jumlah daun berbeda tidak nyata terhadap panjang stek 12 MST. Perlakuan dengan jumlah daun 5 helai daun menunjukkan panjang tunas paling pendek, yaitu 22,80 cm, sedangkan stek dengan jumlah daun 9 helai menunjukkan panjang tunas terpanjang, yaitu $25,15 \mathrm{~cm}$. Pengaruh jumlah daun berbeda tidak nyata terhadap panjang tunas 12 MST diduga akibat meningkatnya respirasi dengan meningkatnya jumlah daun (Tabel 1). Hal ini sesuai dengan pendapat Harjadi (1991) bahwa laju respirasi dipengaruhi oleh banyak faktor, salah satu diantaranya adalah indeks luas daun. Semakin banyak daun yang terdapat pada bahan stek, respirasi yang terjadi semakin besar.

Hasil sidik ragam terhadap diameter tunas bibit jeruk nipis lemon asal stek pucuk menunjukkan bahwa pengaruh jumlah daun berbeda nyata. Rata-rata diameter tunas terbesar ditunjukkan oleh perlakuan 9 helai daun, yaitu $0,23 \mathrm{~cm}$, sedangkan rata-rata diameter terkecil ditunjukkan oleh perlakuan 5 helai daun, yaitu $0,16 \mathrm{~cm}$ (Tabel 1).

Perbedaan diameter tunas yang nyata dengan perbedaan jumlah daun pada stek diduga karena terdapat perbedaan jumlah cadangan makanan dengan perbedaan jumlah daun sebagai organ fotosintesis. Semakin banyak daun, aktivitas proses fotosintesis akan lebih tinggi, sehingga jumlah cadangan makanan yang disimpan pada bahan stek lebih banyak. Cadangan makanan (karbohidrat dan protein) pada stek digunakan sebagai bahan pembentuk komponen sel dan sebagai sumber energi untuk pertumbuhan dan perkembangan tanaman yang meliputi pembelahan, pembesaran dan diferensiasi sel.

Hasil sidik ragam menunjukkan bahwa pengaruh jumlah daun berbeda nyata terhadap jumlah akar. Jumlah akar terbanyak ditunjukkan oleh perlakuan 9 helai daun, yaitu 40,65 akar, sedangkan jumlah akar paling sedikit ditunjukkan oleh perlakuan 5 helai daun, yaitu 27,65 akar (Tabel 1). Hal ini menunjukkan bahwa daun merupakan organ penghasil karbohidrat dan senyawa organik lain melalui proses fotosintesis. Fotosintat tersebut dipakai sebagai sumber energi melalui respirasi untuk pertumbuhan akar. Hal ini sesuai dengan pendapat Rochiman dan Harjadi (2003), yang menyatakan bahwa penyisaan daun pada bahan stek bertujuan agar fotosintesis tetap berlangsung sehingga bahan stek tetap memperoleh energi untuk membantu pembentukan tunas dan akar.

Selain menghasilkan karbohidrat, daun, khususnya daun muda, juga 
merupakan sumber auksin. Auksin bergerak ke bawah dan menumpuk di bagian dasar stek yang selanjutnya menstimulsir pembentukan akar, sebagaimana dikemukakan oleh Mashudi dkk (2008), bahwa cadangan makanan yang disimpan dalam stek merupakan penumpukan hasil fotosintesis. Auksin mampu memacu proses pertumbuhan, yaitu pembelahan, pembesaran dan pemanjangan sel. Energi untuk proses pertumbuhan tersebut diperoleh dari cadangan makanan yang disimpan dalam stek melalui proses respirasi.

Berdasarkan hasil sidik ragam terhadap panjang akar bibit jeruk nipis lemon asal stek pucuk menunjukkan bahwa pengaruh jumlah daun berbeda nyata. Panjang akar terpanjang ditunjukkan oleh perlakuan 9 helai daun, yaitu 23,95 cm, sedangkan panjang akar paling pendek ditunjukkan oleh perlakuan 5 helai daun ,yaitu, 20,99 cm (Tabel 1).

Hasil penelitian menunjukkan bahwa jumlah daun stek berpengaruh terhadap panjang akar melalui proses fotosintesis yang menghasilkan cadangan makanan dalam stek. Semakin banyak daun, proses fotosintesis semakin giat. Cadangan makanan hasil fotosintesis dipakai sebagai substrat pada proses respirasi akan menghasilkan energi yang dipakai untuk pertumbuhan dan perkembangan tanaman, diantaranya untuk pembentukan tunas. Hal ini sesuai dengan pendapat Supriyanto dan Prakasa (2011), yang mengemukakan bahwa bagian tanaman dengan laju fotosintesis yang tinggi akan menghasilkan fotosintat yang tinggi pula dan bahan stek dengan cadangan makanan yang tinggi akan menghasilkan stek dengan daya perakaran tinggi. Selain itu, meristem apikal tunas merupakan tempat sintesis auksin yang berperan dalam pertumbuhan akar. Parnata (2004) menambahkan bahwa auksin dapat mempercepat pembentukan dan perpanjangan batang dan daun serta berperan dalam perpanjangan awal akar.

\section{Pengaruh Konsentrasi Rootone-F terhadap Pertumbuhan Bibit Jeruk Nipis Lemon (Citrus limon L.) Asal Stek Pucuk \\ Berdasarkan hasil sidik ragam,} pengaruh konsentrasi Rootone-F berbeda nyata terhadap saat muncul tunas. Rata-rata saat muncul tunas paling cepat ditunjukkan oleh perlakuan $0,10 \mathrm{~g}$ Rootone-F $\mathrm{mL}^{-1}$ berbeda tidak nyata dengan 0,05 dan $0,15 \mathrm{~g}$ Rootone-F mL ${ }^{-1}$, yaitu berturut-turut: 7,07 ; 7,20 dan 7,53 HST, sedangkan rata-rata saat muncul tunas paling lambat ditunjukkan oleh kontrol, yaitu, 9,07 HST (Tabel 1). Pada umumnya tanaman dapat mensintesis hormon (fitohormon), diantaranya auksin. Auksin berfungsi antara lain untuk mempercepat pertumbuhan dan perkembangan kuncup baru (Parnata, 2004). Namun, konsentrasi auksin endogen dapat berada dibawah optimal, oleh karena itu untuk memacu pertumbuhan tanaman perlu ditambahkan auksin dari luar (auksin eksogen) untuk meningkatkan proses fisiologis dalam stek.

Rootone-F merupakan salah satu merk dagang zat pengatur tumuh yang biasa digunakan sebagai sumber auksin pada penyetekan. Rootone-F memacu aktivitas auksin endogen, sehingga mampu memacu pembentukan tunas pada tanaman. Menurut Gardner et al (1991), auksin berperan sebagai pemicu pembelahan, pembesaran dan pemanjangan sel. Apabila pemberiannya berada pada batas konsentrasi, Rootone-F yang optimum dapat merangsang pertumbuhan tunas, sedangkan pada konsentrasi Rootone-F yang tinggi atau diatas normal, cenderung akan menghambat pertumbuhan tunas. Heddy (1996) menambahkan bahwa Rootone-F memainkan peranan penting melalui pengaruhnya pada pembelahan, pembesaran dan diferensiasi sel. Bila laju pembelahan dan pemanjangan sel serta pembentukan jaringan berjalan cepat, maka pembentukan daun maupun batang berjalan cepat juga.

Hasil sidik ragam terhadap jumlah tunas bibit jeruk nipis lemon asal stek pucuk 
menunjukkan bahwa pengaruh konsentrasi Rootone-F berbeda tidak nyata pada kedua umur pengamatan, yaitu 6 dan 12 MST. Pengaruh konsentrasi Rootone-F tidak nyata terhadap jumlah tunas diduga dipengaruhi oleh faktor genetik dari tanaman itu sendiri. Hal ini sesuai dengan pernyataan Sitompul dan Bambang (1995) yang mengemukakan bahwa perbedaan susunan genetik merupakan penyebab keragaman tanaman. Keragaman penampilan tanaman akibat susunan genetik selalu mungkin terjadi sekalipun tanaman yang digunakan berasal dari jenis tanaman yang sama.

Berdasarkan hasil sidik ragam, pengaruh konsentrasi Rootone-F berbeda tidak nyata terhadap jumlah daun bibit jeruk nipis lemon asal stek pucuk pada 6 MST, tetapi berbeda nyata pada 12 MST (Tabel 1). Pengaruh konsentrasi Rootone-F berbeda tidak nyata pada 6 MST diduga karena kadar auksin dalam stek maupun auksin sintetik/eksogen yang ditambahkan dengan pemberian Rootone-F belum mampu memacu proses pembentukan daun. Zat pengatur tumbuh bekerja pada konsentrasi tertentu untuk memberikan pengaruh yang sifatnya merangsang atau menghambat pertumbuhan.

Pengaruh konsentrasi Rootone-F berbeda nyata terhadap jumlah daun bibit jeruk nipis lemon asal stek pucuk pada 12 MST. Rata-rata jumlah daun 12 MST terbanyak ditunjukkan oleh perlakuan $0,05 \mathrm{~g}$ $\mathrm{mL}^{-1}$ yaitu 23,33 helai, berbeda tidak nyata dengan 010 dan $0,15 \mathrm{~g}$ Rootone-F $\mathrm{mL}^{-1}$, yaitu berturut-turut 20,60 dan 20,00 helai, sedangkan jumlah daun paling sedikit diperoleh pada kontrol, yaitu 14,20 helai (Tabel 1). Hal ini diduga karena pemberian Rootone-F mampu meningkatkan kerja auksin endogen pada stek jeruk nipis lemon sehingga dapat merangsang pembelahan, pembesaran dan diferensiasi sel yang memacu morfogenesis organ tanaman sehingga terbentuknya daun. Menurut Abidin (1990), penambahan Rootone-F paling efektif untuk mempercepat terjadinya pembelahan, perpanjangan dan diferensiasi sel, sehingga pertumbuhan tunas dan daun lebih cepat.

Hasil penelitian menunjukkan bahwa terjadi peningkatan jumlah daun dengan pemberian $0,05 \mathrm{~g}$ Rootone-F $\mathrm{mL}^{-1}$, tetapi diperoleh jumlah daun yang lebih sedikit dengan peningkatan konsentrasi Rootone-F (Tabel 1). Hal ini diduga karena konsentrasi auksin dalam 0,05 g Rootone-F $\mathrm{mL}^{-1}$ sudah cukup untuk merangsang pembentukan daun, tetapi dengan meningkatnya konsentrasi Rootone-F pada 0,10 dan 0,15 g $\mathrm{mL}^{-1}$ justru menyebabkan terhambatnya pembentukan daun. Peningkatan konsentrasi Rootone-F berarti peningkatan konsentrasi auksin dalam stek. Zat pengatur tumbuh (ZPT) akan memacu pertumbuhan pada kisaran konsentrasi tertentu, pada konsentrasi yang lebih tinggi justru akan menyebabkan pertumbuhan menjadi terhambat. Hal ini didukung oleh Abidin (1990), yang menyatakan bahwa zat pengatur tumbuh atau hormon setiap tanaman dalam jumlah sedikit dapat merangsang, tetapi dalam jumlah banyak dapat menghambat dan merubah proses fisiologis. Pamungkas dkk (2009) menambahkan bahwa auksin akan meningkatkan pertumbuhan sampai mencapai konsentrasi yang sesuai. Apabila konsentrasi yang diberikan melebihi konsentrasi yang dibutuhkan, akan mengganggu metabolisme dan perkembangan tanaman, sehingga menurunkan pertumbuhan. Kusuma (2003) menegaskan bahwa dalam mengaplikasikan ZPT perlu diperhatikan ketepatan konsentrasi yang diberikan, karena jika konsentrasi terlampau tinggi bisa menghambat pertumbuhan dan menyebabkan keracunan pada seluruh jaringan tanaman.

Hasil sidik ragam menunjukkan bahwa pengaruh konsentrasi Rootone-F berbeda nyata terhadap panjang tunas bibit jeruk nipis lemon asal stek pucuk pada umur 6 dan 12 MST. Hasil penelitian menunjukkan 
bahwa rata-rata panjang tunas terpanjang diperoleh pada perlakuan $0,10 \mathrm{~g} \mathrm{~mL}^{-1}$, yaitu, 11,47 dan $26,75 \mathrm{~cm}$, diikuti berturutturut oleh perlakuan 0,$50 ; 0,15$ dan $0,00 \mathrm{~g}$ Rootone-F $\mathrm{mL}^{-1}$ (Tabel 1). Semakin tinggi konsentrasi Rootone-F yang dipakai, panjang tunas semakin meningkat sampai $0,10 \mathrm{~g} \mathrm{~mL}^{-1}$, tetapi menurun dengan meningkatnya konsentrasi pada $0,15 \mathrm{~g} \mathrm{~mL}^{-1}$. Peningkatan konsentrasi Rootone-F berarti meningkatkan kadar auksin pada stek. Panjang tunas berhubungan dengan peran auksin dalam pemanjangan sel sebagaimana dikemukakan oleh Salisbury dan Ross (1995), bahwa auksin dihasilkan pada bagian koleoptil (titik tumbuh), berperan dalam pertumbuhan untuk memacu pemanjangan sel. Auksin yang diedarkan ke seluruh bagian tumbuhan mempengaruhi pemanjangan, pembelahan dan diferensiasi sel tumbuhan. Disamping itu, auksin sintetik dalam Rootone-F dan auksin endogen dalam stek bersama-sama mengaktifkan enzim-enzim yang berperan dalam pembentukan komponen sel, sebagaimana dikemukakan oleh Marlin (2005) bahwa auksin mampu mengaktifkan enzim-enzim yang berperan dalam pembentukan komponen sel, sehingga ketika pembelahan sel mulai terjadi, auksin akan merangsang pembentukan sel dengan cepat.

Peningkatan konsentrasi Rootone-F sampai $0,15 \mathrm{~g} \quad \mathrm{~mL}^{-1}$ menyebabkan konsentrasi auksin pada stek melebihi batas konsentrasi optimum, sehingga panjang tunas yang dihasilkan pada konsentrasi 0,15 $\mathrm{g} \mathrm{mL}^{-1}$ lebih pendek dibandingkan dengan konsentrasi dibawahnya (Tabel 1). Auksin akan merangsang pemanjangan sel pada konsentrasi dengan kisaran tertentu, pada konsentrasi yang lebih tinggi, justru akan menyebabkan terhambatnya pemanjangan sel. Hal ini sesuai dengan pendapat Dwidjoseputro (2001), bahwa auksin merupakan istilah generik untuk substansi pertumbuhan yang khusus merangsang perpanjangan sel, tetapi auksin juga menyebabkan suatu kisaran respon pertumbuhan yang agak berbeda-beda. Salisbury dan Ross (1995) menjelaskan lebih lanjut bahwa tumbuhan memperlihatkan respons terhadap auksin, yaitu pada konsentrasi yang optimum terjadi peningkatan laju pertumbuhan, sebaliknya terjadi penurunan pertumbuhan pada konsentrasi yang rendah atau terlalu tinggi. Darliana (2004) menambahkan bahwa penambahan hormon pada tanaman yang diperbanyak dengan cara stek dapat meningkatkan kandungan klorofil pada daun yang menyebabkan proses fotosintesis mengalami peningkatan, sehingga fotosintat yang ditranslokasikan ke organ-organ tanaman lebih banyak, akan tetapi penambahan hormon yang terlalu tinggi cenderung menekan perkembangan klorofil.

Hasil sidik ragam menunjukkan bahwa pengaruh konsentrasi Rootone-F berbeda nyata terhadap diameter tunas bibit jeruk nipis lemon asal stek pucuk. Rata-rata diameter tunas terbaik ditunjukkan oleh perlakuan $0,05 \mathrm{~g} \mathrm{~mL}^{-1}$ yaitu, $0,22 \mathrm{~cm}$, berbeda nyata dengan perlakuan 0,$15 ; 0,10$ dan $0,00 \mathrm{~g}$ Rootone-F $\mathrm{mL}^{-1}$, masing-masing 0,$19 ; 0,18$ dan $0,16 \mathrm{~cm}$. Hal ini diduga pada konsentrasi auksin yang rendah yang dipakai pada penelitian sudah mampu memacu pertumbuhan dan perkembangan yang meliputi pembelahan, pembesaran dan diferensiasi sel, sehingga memacu pembentukan organ tanaman (akar, batang dan daun). Organ tanaman yang berkembang dengan baik menyebabkan proses fisiologis dapat berjalan dengan baik, sehingga pertumbuhan, diantaranya diameter tunas, berjalan dengan baik. Hal ini sesuai dengan pendapat Heddy (1996) yang menyatakan bahwa pengaruh auksin dalam aspek perkembangan tumbuhan diantaranya adalah merangsang pembelahan sel dalam kambium dan mendorong pembelahan sel (batang, akar, dan daun). Parnata (2004) menambahkan bahwa auksin dapat mempercepat pembentukan dan perpanjangan batang serta daun, perpanjangan awal akar dan mempercepat 
pertumbuhan dan perkembangan kuncup baru.

Hasil sidik ragam pengaruh konsentrasi Rootone-F terhadap jumlah akar bibit jeruk nipis lemon asal stek pucuk menunjukkan berbeda nyata. Rata-rata jumlah akar terbanyak ditunjukkan oleh perlakuan $0,10 \mathrm{~g}$ Rootone-F $\mathrm{mL}^{-1}$, yaitu 38,47 akar, namun berbeda tidak nyata dengan perlakuan 0,05 dan 0,15 g Rootone$\mathrm{F} \mathrm{mL}^{-1}$, masing-masing 36,47 dan 36,07 akar, sedangkan rata-rata jumlah akar paling sedikit ditunjukkan oleh kontrol, yaitu 24,93 akar (Tabel 1). Hal ini diduga karena auksin sintetik/eksogen dari Rootone-F bersama dengan auksin endogen dalam stek memacu pertumbuhan akar. Wightman dkk (1980) dalam Salisbury dan Ross (1995) mengemukakan bahwa auksin eksogen memacu pertumbuhan dan perkembangan awal akar. Hal ini sesuai dengan pendapat Rohandi (2010), yang menyatakan bahwa pemberian ZPT yang mengandung auksin memberikan jumlah dan panjang akar yang lebih tinggi dibandingkan dengan stek yang tidak diberikan ZPT auksin. Nursari dkk (2012), menambahkan bahwa Rootone-F adalah salah satu hormon buatan yang dikelompokkan kedalam golongan auksin yang mengandung IAA (Indole Acetic Acid), IBA (Indole Butiric Acid) dan NAA (Napthalene Acetic Acid). Indole Acetic Acid berperan mempercepat pemanjangan sel-sel pada jaringan maristem akar tanaman. IBA dan NAA berperan sangat penting dalam pembentukan akar lanjutan dari akarakar lateral, yaitu pembentukan rambutrambut akar. Auksin sintetik lebih unggul dalam aktivitas perakaran dikarenakan kandungannya lebih stabil, daya kerja lebih lama serta memberikan kemungkinan lebih berhasilnya pembentukan akar.

Berdasarkan hasil sidik ragam, pengaruh Rootone-F menunjukkan berbeda nyata terhadap panjang akar bibit jeruk nipis lemon. Rata-rata panjang akar terpanjang ditunjukkan oleh perlakuan 0,05 g Rootone$\mathrm{F} \mathrm{mL}^{-1}$, yaitu $25,83 \mathrm{~cm}$, diikuti oleh 0,10 dan $0,15 \mathrm{~g} \mathrm{~mL}^{-1}$, berturut-turut 23,32 dan 22,67 cm, sedangkan panjang akar paling pendek ditunjukkan oleh kontrol, yaitu 17,46 cm. Hal ini diduga karena dengan pemberian auksin sintetik dari Rootone-F pada konsentrasi yang tepat akan memacu proses fisiologis, sehingga stek dapat menyimpan cadangan makanan yang cukup untuk pertumbuhan akar, sebagaimana dikemukakan oleh Wardipura dan Solehudin (1983), bahwa ZPT yang ditambahkan pada stek dapat meningkatkan laju transportasi karbohidrat ke dasar stek, sehingga membantu terbentuknya akar karena merupakan bahan kimia yang dapat merangsang proses fisiologis yang memacu perakaran, mempengaruhi perkembangan sel serta meningkatkan sintesis protein. Akibatnya sel-sel mengembang, memanjang dan menyerap air, sehingga sel semakin panjang. Kusumo (1984) menambahkan bahwa zat pengatur tumbuh golongan auksin pada kondisi optimum akan membantu pemanjangan akar, sedangkan pada kadar yang lebih tinggi akan menghambat pemanjangan akar.

\section{KESIMPULAN}

Berdasarkan hasil penelitian, dapat disimpulkan bahwa: 1) Interaksi antara jumlah daun dan konsentrasi Rootone-F berbeda nyata terhadap diameter tunas, tetapi berbeda tidak nyata terhadap saat muncul tunas, jumlah tunas, jumlah daun, panjang tunas terpanjang, jumlah akar dan panjang akar pada semua umur pengamatan; 2) Pengaruh jumlah daun berbeda nyata terhadap saat muncul tunas, jumlah daun, panjang tunas terpanjang, diameter tunas, jumlah akar dan panjang akar bibit jeruk nipis lemon asal stek pucuk, tetapi berbeda tidak nyata terhadap jumlah tunas; 3) Pengaruh konsentrasi Rootone-F berbeda nyata terhadap saat muncul tunas, jumlah daun, panjang tunas terpanjang, diameter tunas, jumlah akar dan panjang akar, tetapi berbeda tidak nyata terhadap jumlah tunas bibit jeruk lemon asal stek pucuk. 


\section{DAFTAR PUSTAKA}

Abidin, Z. 1990. Dasar-dasar Pengetahuan Tentang Zat Pengatur Tumbuh. Angkasa, Bandung.

Badan Pusat Statistik. 2016. Statistik Sayur-sayuran dan Buah-buahan Kalimantan Timur. https://kaltim.bps.go.id. (di akses 30 November 2017).

Darliana, I. 2004. Pengaruh Konsentrasi Rootone-F Terhadap Pertumbuhan Stek Cabang Buah Tanaman Lada (Piper nigrum L.) Kultivar Bulok Belatung. Jurusan Agroteknologi. Fakultas Pertanian UNBAR.

Darmawan, J. dan J. Baharsjah. 1983. Dasardasar Ilmu Fisiologi Tanaman. Suryandaru Utama, Semarang.

Dewi, I.R. 2008. Peranan dan Fungsi Fitohormon bagi Pertumbuhan Tanaman. Fakultas Pertanian Universitas Padjajaran, Bandung.

Dwidjoseputro, D. 2001. Pengantar Fisiologi Tumbuhan. Gramedia Pustaka Utama, Jakarta.

Edmond, J.B., T.C. Seen, F.S. Andrew, and R.G. Halfarce. 1983. Fundamental of Horticulture $4^{\text {th }}$ ed, Mc Graw Hill Pub. New Delhi.

Gardner, F. P., R.B. Pearce, and R.L. Mitchell. 1991. Fisiologi Tamaman Budidaya. UI Press, Jakarta.

Harjadi, S. S. 1991. Pengantar Agronomi. Gramedia, Jakarta.

Hamidin, E. 1983. Pedoman Teknologi Benih. Pembimbing Masa, Jakarta.
Heddy, S. 1996. Hormon Tumbuhan. Raja Grafindo Persada, Jakarta

Hidayanto, M, S. Nurjanah, dan F. Yossita. Pengaruh panjang stek akar dan konsentrasi natrium-nitrofenol terhadap pertumbuhan stek akar sukun (Atrocarpus communis F.). Jurnal Pengkajian Dan Pengembangan Teknologi Pertanian 9.2 (2003): 66-80.

Kusuma, A.S. Pengaruh zat pengatur tumbuh Rootone-F terhadap keberhasilan setek Manglid. J. Agroekoteknologi 5.4 (2003): 780785 .

Kusumo, S. 1984. Zat Pengatur Tumbuh. Yasaguna, Jakarta.

Marlin. Regenerasi in vitro planlet jahe bebas penyakit layu bakteri pada beberapa taraf konsentrasi BAP dan NAA. Jurnal Ilmu-Ilmu Pertanian Indonesia 7.1 (2005): 8-14.

Mashudi, D., Setiadi dan A.F. Ariani. Pertumbuhan tunas tanaman pulai pada beberapa tinggi pangkasan dan dosis pupuk NPK. Jurnal Pemulia Tanaman 2.2. (2008): 1-9.

Nursari, Elda, dan Djumali. Respon tanaman jarak (Jatropa curcas L.) terhadap lima dosis zat pengatur tumbuh (ZPT) asam naftalen asetat (NAA). Agrifor 5.1 (2012): 26-33.

Pamungkas, F.T, S. Darmanti, B. Raharjo. Pengaruh konsentrasi dan lama perendaman dalam supernatan kultur Bacillus sp. 2 DUCCBR- KI. 3 terhadap pertumbuhan stek horizontal batang jarak pagar (Jatropha curcas L.). J. Sains Dan Matematika 17.3 (2009): 131-140. 
Parnata, A.S. 2004. Pupuk Organik dan Pemanfaatannya. Cetakan ke-1. Agromedia Pustaka. Jakarta.

Raharja dan Wiryanta. 2003. Aneka Cara Memperbanyak Tanaman. Agromedia Pustaka, Jakarta.

Rochiman dan S.S. Harjadi. 2003. Pembiakan Vegetatif. Departemen Agronomi. IPB, Bogor. 72 hlm.

Rohadi, A. 2010. Penyediaan bibit mimba melalui perbanyakan stek pucuk dengan aplikasi hormon tumbuhan. Prosiding Seminar Hasil-hasil Penelitian.

Salisbury, F.B. dan C.W. Ross. 1995. Fisiologi Tumbuhan Jilid Tiga. Terjemahan Diah R. Lukman dan Sumaryono. Institut Teknologi Bandung, Bandung.

Sitompul, S.M. dan B. Guritno. 1995. Analisis Pertumbuhan Tanaman. UGM Press, Yogykarta.

Steel, R.G.D. and J.H. Torrie. 1993. Principles and Procedures of Statistics. Terjemahan Bambang Sumantri. Prinsip dan Prosedur Statistika. Suatu Pendekatan Geomatrik. Gramedia, Jakatra.
Supriyanto dan K.E. Prakasa. Pengaruh zat pengatur tumbuh terhadap pertumbuhan stek Duabanga mollucana Blume. Jurnal Silvikultur Tropika 3.1 (2011): 59-65.

Wahid., P. 1990. Pengaruh pemupukan dan pemangkasan tajar hidup terhadap produksi tanaman lada. Pemberitaan Litrri 1.4 .

Wardipura, R. dan S.Solehudin. 1983. Pengaruh Mixtosal dan Atonik terhadap pertumbuhan dan hasil tanaman Stevia rebaudiana berta. BULLETIN AGRONOMI 14.2.

Widiarsih, S., Minarsih, B. Wirawan, dan W.B. Suwarno. 2008. Perbanyakan Tanaman Secara Vegetatif. http://willy.situshijau.co.id. (diakses 26 September 2017).

Wudianto, R. 2003. Membuat Stek, Cangkok, dan Okulasi. Penebar Swadaya, Jakarta. 